\title{
Factors Affecting Postdispersal Weed Seed Predation in Barely Fields
}

\author{
Shahrzad Noroozi, Hasan Mohammad Alizadeh, and Hamid Rahimian Mashhadi
}

Agronomy and Plant Breeding Department, Faculty of Agriculture University of Tehran, Karaj, Iran

Correspondence should be addressed to Shahrzad Noroozi, shnoroozi@ut.ac.ir

Received 8 April 2012; Accepted 12 June 2012

Academic Editors: J. L. Gonzalez-Andujar, M. A. Taboada, and W. P. Williams

Copyright ( $) 2012$ Shahrzad Noroozi et al. This is an open access article distributed under the Creative Commons Attribution License, which permits unrestricted use, distribution, and reproduction in any medium, provided the original work is properly cited.

Seed predation can be exploited as a mean of natural weed control. Field experiments were conducted in 2007 in four barely fields in Mashhad, NE of Iran to determine the effects of seed covering tissues, seed distribution patterns and interactions between seed density and background seed density on postdispersal seed predation. Five weed species (Avena ludoviciana, Hordeum spontaneum, Sinapis arvensis, Rumex obtusifolius and Rapistrum rugosum), three seed densities (50, 100 and 150 seed dish-1), two background seed densities (with and without), three distribution patterns (random, even, and aggregate), and two level of seed covering tissues (with and without) were arrange in a factorial randomized complete block design. Seed covering tissues had significant negative effect on predation and the most its effect was observed for $H$. spontaneum. Seed predation was also affected by seed distribution patterns. The highest and lowest seed predations of all species were observed from aggregate and random treatments respectively. The interaction between density and background seed density affected seed predation. Results show that seed predation can play an important role in decreasing the weed seeds on the soil surface and thus, in soil seed bank. Therefore, seed predation could be considered as a control technique in integrated weed management.

\section{Introduction}

Weeds have been bane of farmers since humanity changed from hunting and gathering to settled agriculture [1]. Annual weeds are the most important weeds in cereal fields that produce large numbers of seeds each year contributing to a seed bank from which the next season's weeds emerge [2]. For these weeds, seed survival is the most important factors affecting their population dynamics [3].

Seeds are dispersed when they are matured and after dispersal, scattered seeds on the ground are exposed to vertebrate and invertebrate predation [4]. Postdispersal seed predation is often the major cause of mortality throughout a plant's life cycle [5] and one of the main processes which affects their population dynamics [6]. Since postdispersal seed predation is a significant source of weed mortality, it can be used in combination with other tactics to reduce reliance on chemical control [7-10].

Determining factors affecting postdispersal seed predation are an important step to quantify its rate. Different studies have shown that agricultural and weed management
[10-12]; environmental conditions [13]; habitat [14, 15], seed characteristics $[16,17]$, weed species $[2,9]$, seed density $[6,10,15,16,18-20]$, background seed density $[12,21]$ and seed distribution pattern [21-23] are all among factors influencing the rate of postdispersal seed predation.

Wild oat (Avena ludoviciana), wild barely (Hordeum spontaneum), wild mustard (Sinapis arvensis), Rumex obtusifolius and turnip weed (Rapistrum rugosum) are important annual weeds in cereal fields in Iran. They produce large number of seeds annually that are prone to seed predation. Appropriate measures enhance predator presence in the field.

The objectives of this research were to determine the effect of (i) seed covering tissues, (ii) seed distribution pattern, and (iii) interaction between seed density and background seed density on postdispersal weed seed predation in barely fields.

\section{Material and Method}

Field experiments were conducted in 2007 in four barley fields (fields \#1, \#2, \#3, and \#4) in Mashhad $\left(36^{\circ} 16^{\prime} \mathrm{N}\right.$, 
$\left.59^{\circ} 38^{\prime} \mathrm{E}\right), \mathrm{NE}$ of Iran. Treatments were arranged in a randomized complete block design in $8 * 30 \mathrm{~m}$ plots and replicated four times. Seeds were placed on a layer of sieved field soil contained within $10 \mathrm{~cm}$ diameter polystyrene Petri dishes that had several drainage holes in the base. 10 dishes were used in each plot and each dishes contained 50 seeds of a single species. Petri dishes were buried, flush with the soil surface. To determine the sources of seed loss other than predation, in each plot, one Petri dish was placed in a $1 \mathrm{~mm}$ wire mesh cage as control. Experiment was conducted from June 24th to August 5th, 2007 using six sequential 1-week trials. At the end of each week, all Petri dishes were collected and were replaced with new dishes.

2.1. Effect of Seed Covering Tissues. The experiments were conducted in two barley fields. Field \#1 was surrounded by an alfalfa field, two fallow nonplowed fields and a wheat field. Railroad, a wheat field, a follow plowed field and a potato field surrounded field \#2. Seed covering tissue (with and without), weed species (A. ludoviciana, H. spontaneum, and $R$. obtusifolius) and date of sampling (six sequential weeks) were experimental treatments that were arranged in a randomized complete block design in $8 * 30 \mathrm{~m}$ plots and replicated four times.

2.2. Effect of Distribution Pattern. Three distribution patterns (patchy, random, and even) were used to explore the effect of distribution pattern of weed plants on postdispersal seed predation of A. ludoviciana, H. spontaneum, S. arvensis, and $R$. rugosum in field \#3. In the random treatment, all dishes were randomly placed in plots to simulate single plants distribution in field. For patchy treatment, all dishes were placed in one point close to each other in a place which was randomly selected each week. In the even treatment, 10 dishes were placed in two rows, six meters apart; each row had five dishes, six meters apart in zigzag pattern.

2.3. Effect of Seed Density and Background Seed Density. Seed density $\left(50,100\right.$, and 150 seeds dish $\left.{ }^{-1}\right)$, background seed density (with and without), weed species (A. ludoviciana, $H$. spontaneum, $S$. arvensis, and $R$. rugosum), and date of sampling (6 sequential 1-week) were experimental treatments that were performed in field \#4. For R. rugosum, silicula were used because after dispersal, seeds are still incased in silicula. To determine background seed density, it was assumed that background seeds were distributed in a $60 \mathrm{~cm}$ diameter circle around each dish. The area of this circle was calculated. For S. arvensis, it was assumed one seed $\mathrm{cm}^{-2}$ background circle. For $R$. rugosum, the procedure was the same except silicula were used instead of seeds but for A. ludoviciana and $H$. spontaneum, one seed $0.25 \mathrm{~cm}^{-2}$ and the others $0.36 \mathrm{~cm}^{-2}$ were used respectively. The number of seeds required for background of each weed was calculated according to the species 1000-seed weight, $(22,59,54$, and 69 grams for $S$. arvensis, $R$. rugosum, A. ludoviciana and $H$. spontaneum seeds, resp.). The background seeds were replaced each week as they were removed by predators.

\section{Statistical Analysis}

After collecting dishes, remained seeds in dishes were counted and compared with the data from control dishes. Prior to analysis, all subsample measurements made in the same plot on the same date were averaged. For normality and homogeneity of error variance, all data were $\operatorname{Arcsin} \sqrt{X}$ transformed. Since the density of seeds in dishes was not equal in the effect of seed density and background seed density experiment, predation was calculated as percentage of highest predated seeds in the experiment. Means were separated by LSD's tests $(P<0.05)$. Data were analyzed using PROC GLM procedure (SAS Version 9.0).

\section{Results}

No seed was lost from the control dishes. The calm weather during the six weeks of experiment was helpful in maintaining seeds in Petri dishes. Seed covering tissues had significant negative effect on predation. In both fields and for all species, seed predation of seeds with covering tissues was lower than seeds without covering tissues (Figure 1), but the effect of seed covering tissues on predation of all species was not the same. It had the highest and lowest significant negative effect on predation of $H$. spontaneum and $R$. obtusifolius seeds (Figure 1). For all three weeds species, postdispersal seed predation was higher in field \#1 than field \#2 (Figure 1). In field \#1, the highest and lowest seed predation was $63 \%$ and $33 \%$, belonging to A. ludoviciana seeds without seed covering and $H$. spontaneum seeds with seed covering tissues respectively. The same trend was observed in field $\# 2$, but the predation rate was $49 \%$ and $27 \%$ for A. ludoviciana and $H$. spontaneum, respectively (Figure 1).

Distribution pattern had also significant effect on postdispersal seed predation of all tested species (Figure 2). Seed predation was highest and lowest when distribution was aggregate and random, respectively.

Seeds predation of four tested species was affected by interaction between density and background density, but such significance was not observed for $H$. spontaneum. For S. arvensis and A. ludoviciana, seed density had no effect on predation in the absence of background seed density but in the presence of background density, seed density had significant positive effect on predation of these two weed species. The same was observed for R. rugosum (Table 1 ). In the absence of background seed density, seed predation was not different between 50 and 100 seed dishes ${ }^{-1}$ densities of $R$. rugosum, but these two were significantly different in 150 seed dish $^{-1}$ density treatment. Background density had no significant effect on seed predation of $H$. spontaneum at all seed densities. There were no differences between seed predation in 100 and 150 seed dish ${ }^{-1}$ no background seed densities of $H$. spontaneum but they were different from 50seed density (Table 1).

\section{Discussion}

Total weed predation was different among fields, and our results were similar to other experiments on seed predation 


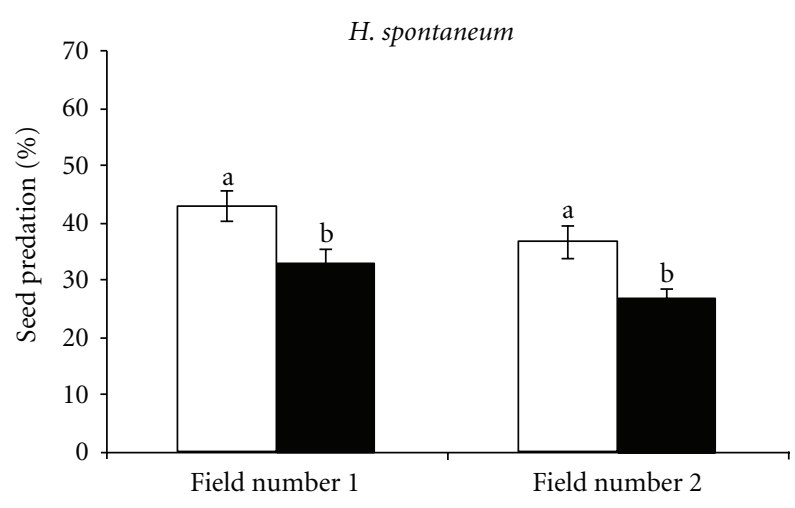

(a)



(c)

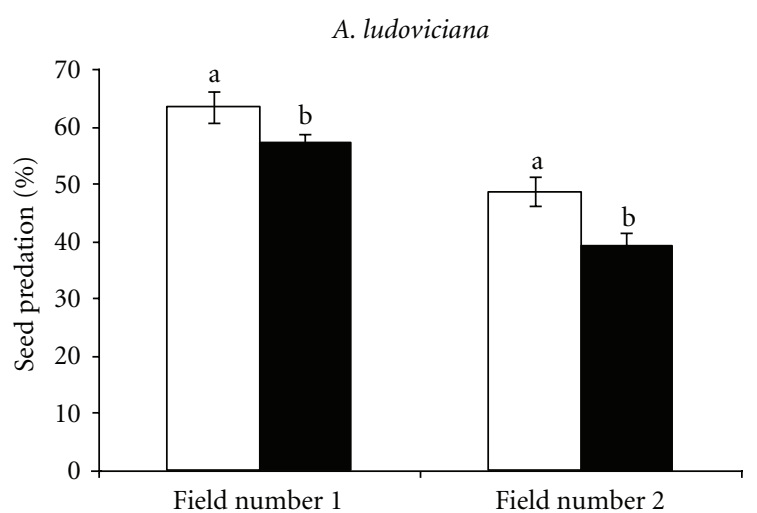

(b)

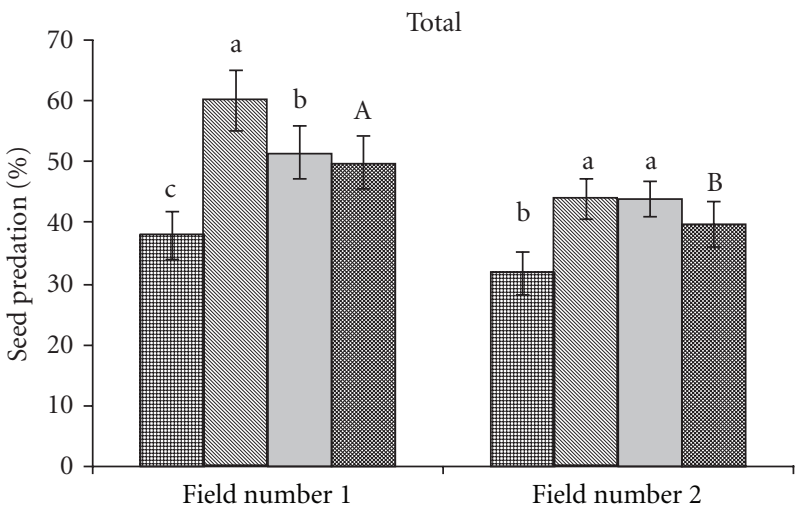

(d)

Figure 1: Mean predation of A. ludoviciana, R. obtusifolius and H. spontaneum seeds during six weeks of experiment in two barley fields. Error bars represent the standard error of the means (SE). Within fields, the means with the same letter are not significantly different according to LSD test $(\alpha=0.05)$. In graphs (a), (b) and (c), the white columns are without seed covering tissue and the black ones are with seed covering tissues treatment. In graph (d): field number 1: First column (c) represents: H. spontaneum, second column (a) represents: A. ludoviciana, third column (b) represents: R. obtusifolius, forth column (A) represents: Mean predation, field number 2: First column (b) represents: H. spontaneum, second column (a) represents: A. ludoviciana, third column (a) represents: R. obtusifolius and forth column (B) represents: Mean predation.

$[7,13,24]$. Since several factors effect seed predation, the results can highly be variable between fields.

In seed covering tissues experiment, predation was higher in field \#1, which was surrounded by a four-year alfalfa field, two fallow plowed fields, and a wheat field, while field \#2 was surrounded by railroad, a wheat field, a follow, plowed field and a potato field. Surrounding area of field \#1 was more stable than field \#2. The alfalfa field had not been plowed for four years. The circumstances of fallow fields were clear. Therefore, disturbance in surrounding areas of field $\# 1$ was less than the field \#2. Since disturbance has negative effect on predation, it could explain to some extent, why seed predation was higher in field \#1. It was predicted that seed predation would be higher in landscapes with higher noncropped habitats because in such habitats, the diversity of seed predators' fauna is higher. Because of the linkage between seed predators and noncrop habitat, it follows that the relative abundance of noncrop habitats in an agricultural landscape may have an effect on weed seed predation within crop fields. As such, it should be expected that predation on weed seeds would be lower in simplified than in complex agricultural landscapes [7].

Seed predators often feed preferentially on one species over another $[17,25,26]$. In our experiments, predation of different weeds and even the same weed in different fields was variable. Our results were in agreement with the results of Heggenstaller et al. [11] and Westerman et al. [13]. Westerman et al. [13] showed that seed predation of Avena fatua was greater than Chenopodium album and Stellaria media, while Jacob et al. [2] reported that Lolium rigidum seeds were preferred over Avena fatua seeds, followed by Raphanus raphanistrum pod segments.

Seed size can be a factor affecting the preference of the granivores [27]. In our experiments, A. ludoviciana had highest seed predation in two experiments while $H$. spontaneum followed by $R$. obtusifolius had the lowest seed predation. It is suggested that the differences between species in loss to predators maybe partially related to degree of their hardness [28]. In H. spontaneum, Lemma and palea that are hidebound to seed could be barriers to predators accessing 
S. arvensis

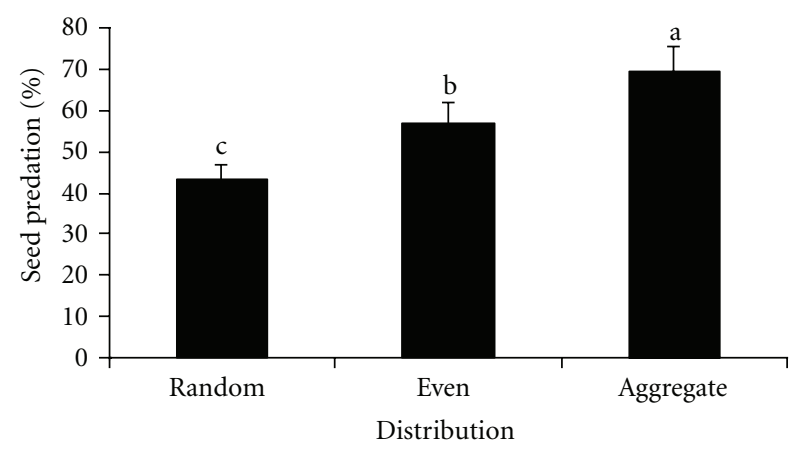

(a)

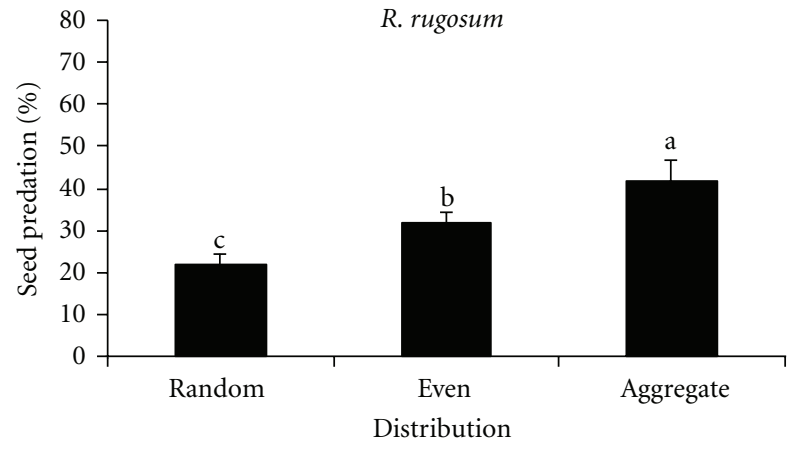

(c)

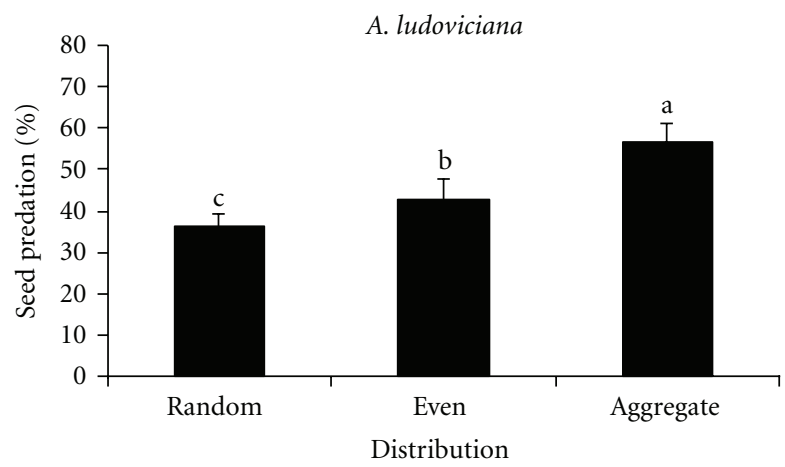

(b)

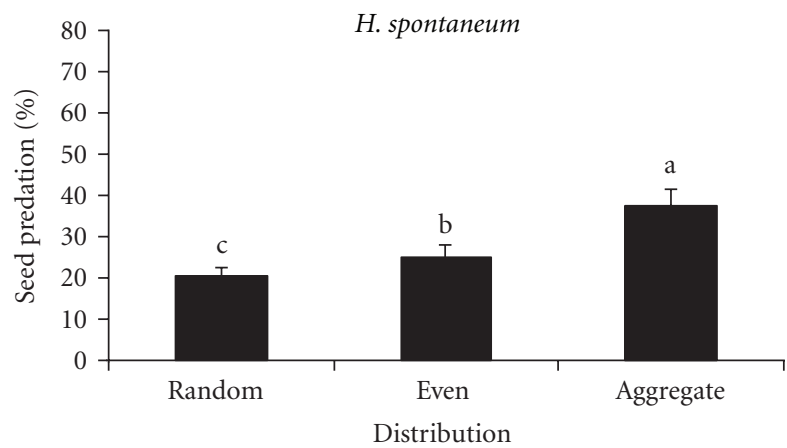

(d)

Figure 2: Mean predation of A. ludoviciana, H. spontaneum, S. arvensis and R. rugosum seeds during six weeks of experiment. Error bars represent the standard error of the means (SE). Within fields, the means with the same letter are not significantly different according to LSD test $(\alpha=0.05)$.

TABLE 1: Mean percentage of seed predation \pm SE at different interactions of density and background density.

\begin{tabular}{lccccc}
\hline & & & \multicolumn{3}{c}{ Weed species } \\
Density (seeds dish $\left.{ }^{-1}\right)$ & Background & S. arvensis & A. ludoviciana & R. rugosum & H. spontaneum \\
\hline \multirow{2}{*}{50} & With & $49 \pm 7 \mathrm{c}$ & $43 \pm 8 \mathrm{c}$ & $29 \pm 5 \mathrm{c}$ & $27 \pm 5 \mathrm{a}$ \\
& Without & $37 \pm 5 \mathrm{~d}$ & $33 \pm 7 \mathrm{~d}$ & $22 \pm 6 \mathrm{e}$ & $19 \pm 5 \mathrm{c}$ \\
\multirow{2}{*}{100} & With & $64 \pm 10 \mathrm{~b}$ & $54 \pm 11 \mathrm{~b}$ & $38 \pm 7 \mathrm{~b}$ & $28 \pm 5 \mathrm{a}$ \\
& Without & $36 \pm 6 \mathrm{~d}$ & $32 \pm 7 \mathrm{~d}$ & $51 \pm 7 \mathrm{a}$ & $21 \pm 4 \mathrm{~b}$ \\
150 & With & $82 \pm 11 \mathrm{a}$ & $76 \pm 10 \mathrm{a}$ & $23 \pm 5 \mathrm{~d}$ & $22 \pm 5 \mathrm{~b}$ \\
\hline
\end{tabular}

* Data with same word in the same column were not significantly different.

to the bare seeds. Seeds of R. obtusifolius are enclosed in weak tissues that are easier to remove than covering tissues of A. ludoviciana and H. spontaneum seeds. However, the differences between species in seed loss may also be related to other traits such as seed weight [29], seed shape [4], and seed size $[2,9,29,30]$. It should be considered that predators' seed preference is not consistence in time and places.

Weed population distributions are usually patchy so that their seed distribution would be patchy too [31]. Seed distribution pattern has been considered as one of the important affecting factors on seed predation. It has been considered that seed aggregation would increase their predation by ants $[32,33]$. Our results also showed that seed predation from treatments with patchy distribution was higher than that, followed by random distributions. This result was in agreement by Marino et al. [21], who showed that as the aggregation of C. album increased, its predation also increased too.

For A. ludoviciana and S. arvensis, interaction of density and background density had significant effect on predation while in the absence of any seed background, density had no significant effect on predation. It seems that for species with high preference, density alone does not play an important role in predation but when there is some seeds distributed around the dishes that attract the predators, seed density would be effective. 
For R. rugosum and at the presence of background seed density, situation is like densities of A. ludoviciana and $S$. arvensis but at the absence of background density, there was no difference between predation of 50 and 100 seeds dish ${ }^{-1}$, but seed predation from 150 seed dish ${ }^{-1}$ differed significantly with them. Maybe the high density of 150 seed density dishes appealed the predators to continue predation.

In $H$. spontaneum, density and background interaction were not significant. If background seed availability is high, one might expect low predation on seed cards because there are alternative seed resources available [12]. We suggest that for high-preference species like A. ludoviciana and S. arvensis, density alone does not have an effect on predation rate but when there are seeds scattering around the clump, the interaction between density and background has positive effect on predation. For low-preference species like $H$. spontaneum, background had no effect on predation, but increasing density especially at low densities (from 50 to 100 seed dish $^{-1}$ ) affected the predation. Finally, for moderate preference species like $R$. rugosum, density and background interaction is similar to high-preference species, but density has an effect on predation was only observed in high densities.

The overall goal of weed science is to establish the optimum strategies for weed management [34]. An important weed control method is controlling population dynamics and destruction of a significant percentage of the weed seeds produced in a field will impact the following year's weed density [35]. It has been shown that seed predation, effects on soil seed bank and is partly responsible for its decline $[2,13,24]$.

With respect to the amount of seed predation of different species, we can conclude that seed predation can play an important role in decreasing the seeds of many weed species on the soil surface and thus in soil seed bank. Therefore, seed predation could be considered as a control technique in integrated weed management. Of course, reliance on this method is different between species. Results showed that the importance of this control method in integrated management of $H$. spontaneum is not as equal as its importance in integrated management of A. ludoviciana followed by $R$. obtusifolius. Further experiments should be conducted in different regions and even different fields to confirm the consistency of our suggestions in different habitat and different weed seed species.

\section{Acknowledgments}

This study was financially supported by University of Tehran. The authors wish to thank the farmers for allowing us to use their fields and for their hospitality. The authors greatly appreciate Dr. Mohhamad Reza Naghavi for his assistance in statistical analysis.

\section{References}

[1] S. Powles and D. Shaner, Herbicide Resistance and World Grain, CRC Press, Boca Raton, Fla, USA, 2001.
[2] H. S. Jacob, D. M. Minkey, R. S. Gallagher, and C. P. Borger, "Variation in postdispersal weed seed predation in a crop field," Weed Science, vol. 54, no. 1, pp. 148-155, 2006.

[3] A. S. Davis, P. M. Dixon, and M. Liebman, "Using matrix models to determine cropping system effects on annual weed demography," Ecological Applications, vol. 14, no. 3, pp. 655668, 2004.

[4] A. Honek, P. Saska, and Z. Martinkova, "Seasonal variation in seed predation by adult carabid beetles," Entomologia Experimentalis et Applicata, vol. 118, no. 2, pp. 157-162, 2006.

[5] R. Nathan and R. Casagrandi, "A simple mechanistic model of seed dispersal, predation and plant establishment: JanzenConnell and beyond," Journal of Ecology, vol. 92, no. 5, pp. 733-746, 2004.

[6] P. E. Hulme, "Post-dispersal seed predation: consequences for plant demography and evolution," Perspectives in Plant Ecology, Evolution and Systematics, vol. 1, no. 1, pp. 32-46, 1998.

[7] F. D. Menalled, P. C. Marino, K. A. Renner, and D. A. Landis, "Post-dispersal weed seed predation in Michigan crop fields as a function of agricultural landscape structure," Agriculture, Ecosystems and Environment, vol. 77, no. 3, pp. 193-202, 2000.

[8] A. S. Davis, P. M. Dixon, and M. Liebman, "Cropping system effects on giant foxtail (Setaria faberi) demography: II. Retrospective perturbation analysis," Weed Science, vol. 51, no. 6, pp. 930-939, 2003.

[9] E. R. Gallandt, T. Molloy, R. P. Lynch, and F. A. Drummond, "Effect of cover-cropping systems on invertebrate seed predation," Weed Science, vol. 53, no. 1, pp. 69-76, 2005.

[10] P. R. Westerman, M. Liebman, F. D. Menalled, A. H. Heggenstaller, R. G. Hartzler, and P. M. Dixon, "Are many little hammers effective? Velvetleaf (Abutilon theophrasti) population dynamics in two- and four-year crop rotation systems," Weed Science, vol. 53, no. 3, pp. 382-392, 2005.

[11] A. H. Heggenstaller, F. D. Menalled, M. Liebman, and P. R. Westerman, "Seasonal patterns in post-dispersal seed predation of Abutilon theophrasti and Setaria faberi in three cropping systems," Journal of Applied Ecology, vol. 43, no. 5, pp. 999-1010, 2006.

[12] M. E. O’Rourke, A. H. Heggenstaller, M. Liebman, and M. E. Rice, "Post-dispersal weed seed predation by invertebrates in conventional and low-external-input crop rotation systems," Agriculture, Ecosystems and Environment, vol. 116, no. 3-4, pp. 280-288, 2006.

[13] P. R. Westerman, J. S. Wes, M. J. Kropff, and W. Van Der Werf, "Annual losses of weed seeds due to predation in organic cereal fields," Journal of Applied Ecology, vol. 40, no. 5, pp. 824-836, 2003.

[14] P. E. Hulme, "Post-dispersal seed predation by small mammals," in Proceedings of the International Symposium of the Zoological Society of London, vol. 65, pp. 269-287, 1993.

[15] P. E. Hulme, "Post-dispersal seed predation in grassland: its magnitude and sources of variation," Journal of Ecology, vol. 82, no. 3, pp. 645-652, 1994.

[16] G. E. Brust and G. J. House, "Weed seed destruction by arthropods and rodents in low-input soybean agroecosystems," American Journal of Alternative Agriculture, vol. 3, pp. 19-35, 1988.

[17] S. K. Harrison, E. E. Regnier, and J. T. Schmoll, "Postdispersal predation of giant ragweed (Ambrosia trifida) seed in notillage corn," Weed Science, vol. 51, no. 6, pp. 955-964, 2003.

[18] A. Honěk and V. Jarošík, "The role of crop density, seed and aphid presence in diversification of field communities of Carabidae (Coleoptera)," European Journal of Entomology, vol. 97, no. 4, pp. 517-525, 2000. 
[19] A. Honek and Z. Martinkova, "Aggregation of ground beetles Carabidae, (Coleoptera) on winter rape seeds dispersed on the ground," Plant Protection Science, vol. 37, pp. 97-102, 2001.

[20] A. Honek, Z. Martinkova, and P. Saska, "Post-dispersal predation of Taraxacum officinale (dandelion) seed," Journal of Ecology, vol. 93, no. 2, pp. 345-352, 2005.

[21] P. C. Marino, P. R. Westerman, C. Pinkert, and W. Van Der Werf, "Influence of seed density and aggregation on postdispersal weed seed predation in cereal fields," Agriculture, Ecosystems and Environment, vol. 106, no. 1, pp. 17-25, 2005.

[22] M. F. Willson and C. J. Whelan, "Variation in postdispersal survival of vertebrate-dispersed seeds: effects of density, habitat, location, season, and species," Oikos, vol. 57, no. 2, pp. 191-198, 1990.

[23] D. S. Hammond, "Post-dispersal seed and seedling mortality of tropical dry forest trees after shifting agriculture," Journal of Tropical Ecology, vol. 11, pp. 295-313, 1995.

[24] P. R. Westerman, A. Hofman, L. E. M. Vet, and W. Van Der Werf, "Relative importance of vertebrates and invertebrates in epigeaic weed seed predation in organic cereal fields," Agriculture, Ecosystems and Environment, vol. 95, no. 2-3, pp. 417-425, 2003.

[25] C. M. Ghersa and M. A. Martínez-Ghersa, "Ecological correlates of weed seed size and persistence in the soil under different tilling systems: implications for weed management," Field Crops Research, vol. 67, no. 2, pp. 141-148, 2000.

[26] F. D. Menalled, R. G. Smith, J. T. Dauer, and T. B. Fox, "Impact of agricultural management on carabid communities and weed seed predation," Agriculture, Ecosystems and Environment, vol. 118, no. 1-4, pp. 49-54, 2007.

[27] S. J. Willott, S. G. Compton, and L. D. Incoll, "Foraging, food selection and worker size in the seed harvesting ant Messor bouvieri," Oecologia, vol. 125, no. 1, pp. 35-44, 2000.

[28] A. A. Muñoz and L. A. Cavieres, "A multi-species assessment of post-dispersal seed predation in the central Chilean Andes," Annals of Botany, vol. 98, no. 1, pp. 193-201, 2006.

[29] C. S. Blaney and P. M. Kotanen, "Post-dispersal losses to seed predators: an experimental comparison of native and exotic old field plants," Canadian Journal of Botany, vol. 79, no. 3, pp. 284-292, 2001.

[30] H. M. Alexander, C. L. Cummings, L. Kahn, and A. A. Snow, "Seed size variation and predation of seeds produced by wild and crop-wild sunflower," American Journal of Botany, vol. 88, pp. 623-627, 2001.

[31] R. R. Forcella, G. Wilson, K. Renner et al., "Weed seed banks of the US cornbelt: magnitude, variation, emergence, and application,” Weed Science, vol. 40, pp. 636-644, 1992.

[32] L. Hughes and M. Westoby, "Removal rates of seeds adapted for dispersal by ants," Ecology, vol. 71, no. 1, pp. 138-148, 1990.

[33] E. Gorb and S. Gorb, "Effects of seed aggregation on the removal rates of elaiosome-bearing Chelidonium majus and Viola odourata seeds carried by Formica polyctena ants," Ecological Research, vol. 15, no. 2, pp. 187-192, 2000.

[34] R. F. Norris, "Weed fecundity: current status and future needs," Crop Protection, vol. 26, no. 3, pp. 182-188, 2007.

[35] B. Hartzler, M. Liebman, and P. Westerman, "Weed Seed Predation in Agricultural Fields," 2006, http://www.weeds.iastate .edu/mgmt/2006/seedpredation.pdf. 


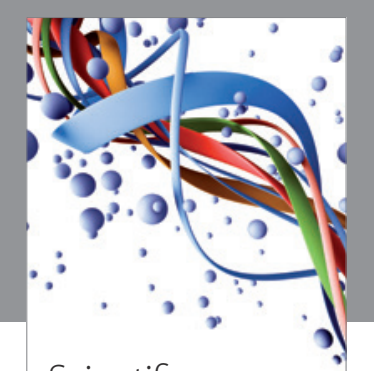

Scientifica

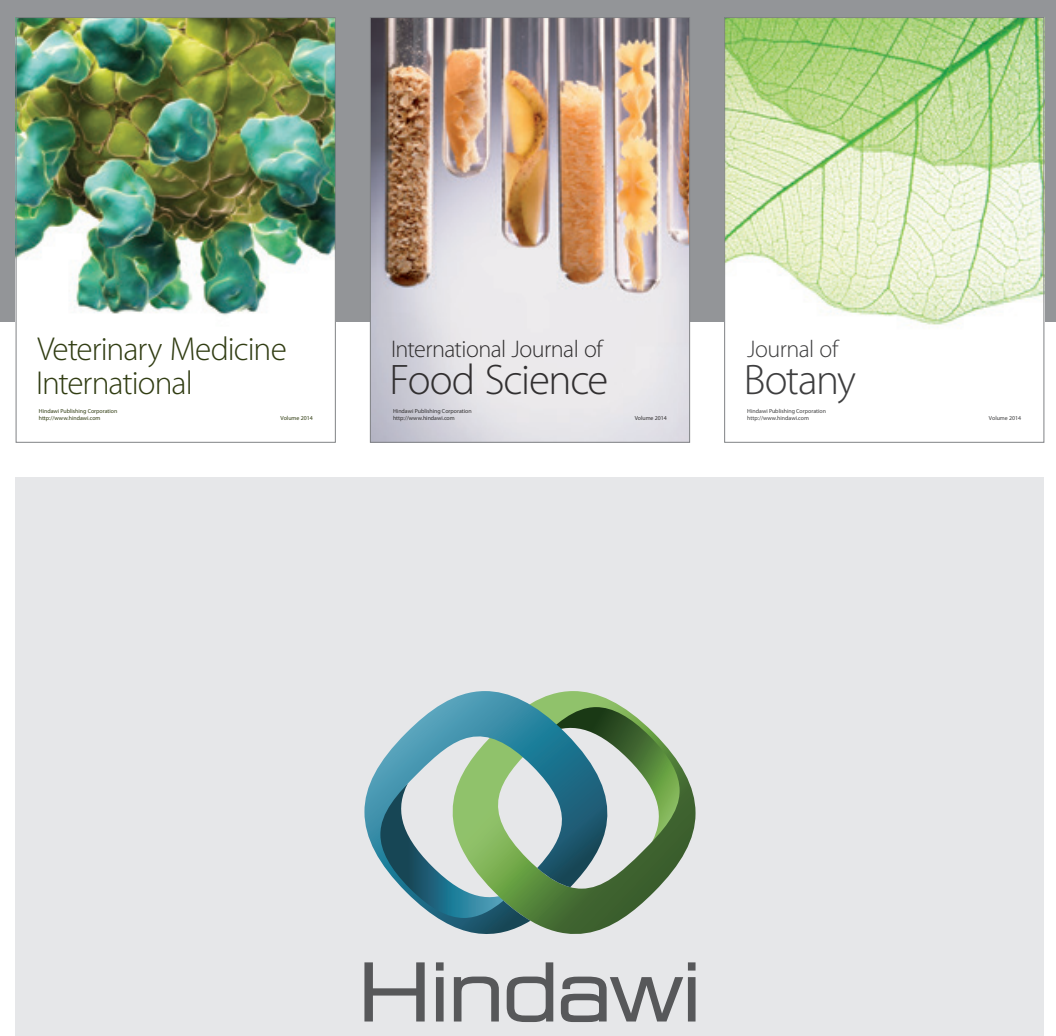

Submit your manuscripts at

http://www.hindawi.com
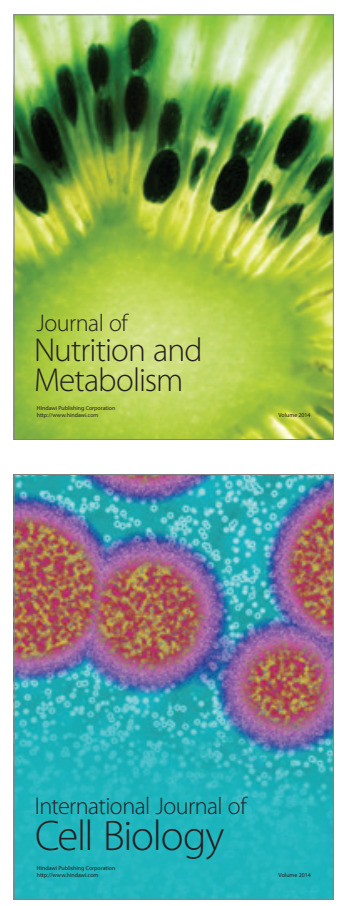
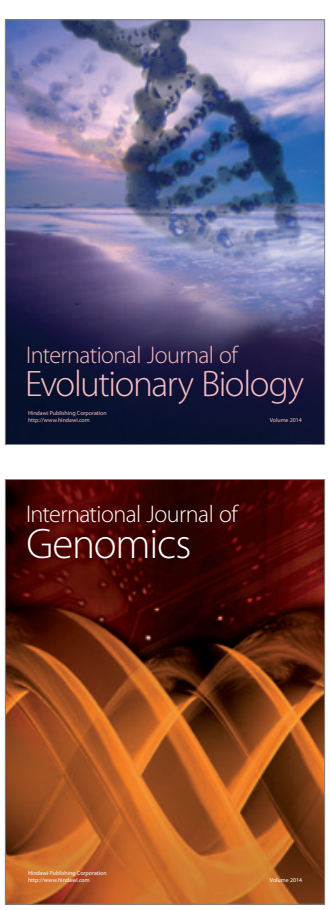
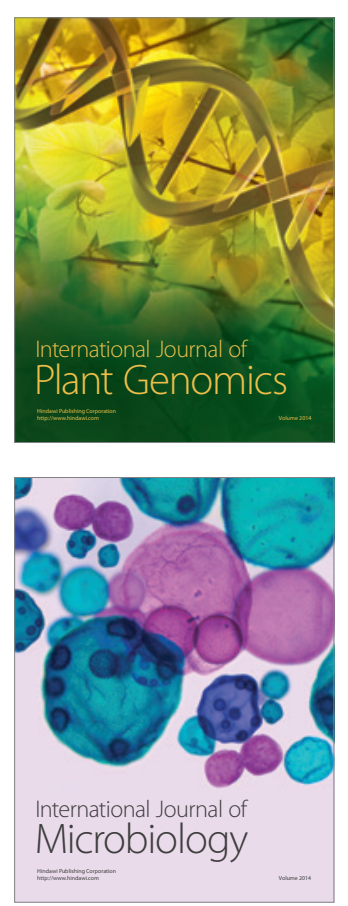

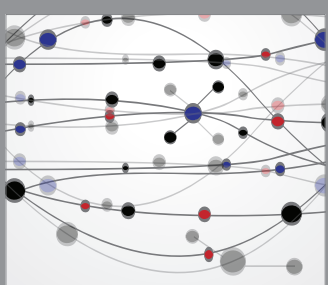

The Scientific World Journal
